\title{
PERAN DAN KONTRIBUSI MAJELIS TA'LIM TERHADAP PENINGKATAN RELIGIUSITAS MASYARAKAT DI PERUMAHAN JIWAN 002/006, NGEMPLAK, KARTASURA
}

\author{
Sudigdo \\ Sahal Abidin \\ Universitas Nahdlatul Ulama Surakarta
}

\begin{abstract}
Abstrak
Tujuan dari penelitian ini adalah untuk mengetahui peran dan kontribusi majelis ta'lim terhadap peningkatan religiusitas masyarakat. Penelitian ini termasuk jenis penelitian lapangan. Hasil penelitian menunjukkan bahwa usaha-usaha peningkatan religiusitas masyarakat, yaitu dengan melakukan perencanaan dalam pengelolaan majelis taklim dan kemudian setelah rencana dilaksanakan perlu dilakukan evaluasi tentang ada dan tidaknya pengaruh pendidikan di majelis ta'lim dengan peningkatan religiusitas masyarakat. Pengaruh Majelis Ta'lim memiliki pengaruh yang sangat besar terhadap religiusitas masyarakat. Apabila majlis ta'lim ditingkatkan 40\%, maka religiusitas masyarakat akan bertambah 0,2427 (40) $=9,71$ angka.
\end{abstract}

Kata kunci: Religiusitas, Majelis Taklim

\begin{abstract}
.
This study aimed to find out the role and contribution of the ta'lim assembly to the improvement of community religiosity. This research includes this type of field research. The results showed that efforts to increase community religiosity, namely by planning in the management of the ta'lim assembly and then after the plan was implemented, it was necessary to evaluate the existence and absence of educational influence in the ta'lim group an increase in community religiosity. The result of the Ta'lim Assembly had a
\end{abstract}


significant impact on the religiosity of society. If the ta'lim council is increased by $40 \%$, then the religiosity of the community will increase by $0.2427(40)=9.71$ numbers.

Keywords: Religiousity, Taklim

\section{A. PENDAHULUAN}

Pendidikan, merupakan hal yang sangat penting karena pendidikan merupakan aktifitas bimbingan yang disengaja untuk mencapai kepribadian berkenaan dengan dimensi jasmani, rohani, akal dan moral.' Dengan bimbingan untuk mencapai kepribadian yang berkenaan dengan berbagai dimensi tersebut, dengan pendidikan akan terwujud pribadi-pribadi yang memiliki kekuatan spiritual keagamaan, pengendalian diri, kepribadian, kecerdasan, akhlak mulia, serta ketrampilan yang diperlukan oleh dirinya, masyarakat, bangsa dan negara. ${ }^{2}$

Pendidikan, dapat dipahami pula dengan arti tahapan pengubahan sikap dan tingkah laku manusia baik sebagai individu maupun sebagai kelompok melalui ikhtiar pengajaran dan pelatihan. ${ }^{3}$

Sebagaimana definisi di atas, maka dapat dipahami tentang tujuan dari Pendidikan Islam. Zakiyah Daradjat dalam bukunya juga menjelaskan bahwa tujuan pendidikan Islam adalah kepribadian seseorang yang membuatnya menjadi insan kamil, yakni manusia utuh ruhani dan jasmani, dapat hidup dan berkembang secara wajar dan normal karena taqwanya kepada Allah SWT. ${ }^{4}$ Dengan beberapa definisi dan penjelasan tersebut, maka sebagaimana yang dijelaskan oleh Djumali dkk, bahwa dikatakan pendidikan jika dalam kegiatan tersebut mencakup hasil rambahannya pengetahuan sekaligus kepribadian, sedangkan pengajaran membatasi kegiatan pada transfer of knowledge yang kawasannya tidak membentuk kepribadian. ${ }^{5}$

Majelis Ta'lim merupakan merupakan model pendidikan yang

\footnotetext{
${ }^{1}$ Hasan Basri, Landasan Pendidikan (Bandung: Pustaka Setia, 2013), hal. 26.

2 Abdul Latif, Pendidikan Berbasis Nilai Kemasyarakatan, cetakan II (Bandung: Refika Aditama, 2009), hal. 7.

${ }^{3}$ Muhibbin Syah, Psikologi Pendidikan dengan Pendekatan Terbaru, cetakan XIX (Bandung: Remaja Rosdakarya, 2014), hal. 35.

${ }^{4}$ Zakiah Daradjat, dkk, Ilmu Pendidikan Islam, cet-VIII (Jakarta: Bumi Aksara, 2009), hal. 29.

${ }^{5}$ Djumali, dkk, Landasan Pendidikan (Yogyakarta: Gava Media, 2013), hal. 28.
} 
banyak berkembang di masyarakat. Perkembangan kuantitas majelis ta'lim tersebut memberikan gambaran akan pentingnya ilmu dan pendidikan dalam kehidupan manusia. Dalam konsep ajaran Islam, ilmu merupakan hal yang sangat penting dan memiliki nilai yang tinggi. Apresiasi Islam terhadap ilmu bukan hanya terletak pada pujian kepada ilmu, namun juga pujian dan apresiasi terhadap pencari ilmu. Hal itu dibuktikan dengan banyaknya penjelasan dalam al-Qur'an dan juga hadis Rasulullah SAW yang berkaitan dengan hal tersebut, seperti janji ditinggikan derajat bagi orang yang beriman dan berilmu (Q.s. al-Mujadalah: 11), jaminan syurga bagi orang yang mencari ilmu, bahkan nilai jihad bagi orang yang pergi mencari ilmu.

Berbagai jaminan dan apresiasi yang diberikan Islam terhadap ilmu dan pencarinya, karena dengan ilmu manusia akan memahami dan sadar akan fungsi dan tujuan serta tugasnya, yaitu beribadah kepada Allah SWT. ${ }^{6}$

Berdasarkan pada penjelasan akan pentingnya ilmu, maka pendidikan menjadi sesuatu hal yang sangat penting. Alasan yang mendasari statemen tersebut adalah bahwa untuk menanamkan keyakinan akan tugas dan tanggung jawabnya, dibutuhkan suatu proses pendidikan. Selain itu, pentingnya pendidikan juga disebabkan karena agama akan dapat dihayati dan diamalkan apabila dididik melalui proses pendidikan.?

Dengan pendidikan, maka akan lahir manusia-manusia 'abid yang penuh kesadaran, memiliki kemampuan intelektual dan spiritual. Dengan demikian, lahirlah berbagai pandangan hidup, tauhid, baik rububiyyah, uluhiyyah maupun ubudiyah, yang meyakini kesatuan penciptaan, kesatuan kemanusiaan, kesatuan tuntunan hidup, yang semua itu merupakan deriviasi dari kesatuan ketuhanan. ${ }^{8}$ Dari sinilah dapat diketahui hubungan antara ilmu, pendidikan dan agama.

Pendidikan sendiri mempunyai peran yang sangat penting untuk menjamin perkembangan dan kelangsungan kehidupan suatu bangsa. Pendidikan itu juga berupaya untuk menjamin kelangsungan hidup bangsa tersebut. Sebab, lewat pendidikanlah akan diwariskan nilai-nilai luhur yang

\footnotetext{
${ }^{6}$ Abdul Madjid, Pendidikan Agama Islam Berbasis Kompetensi, (Bandung: PT Remaja Rosda Karya, 2005), hal. 130.

${ }^{7}$ Zakiah Daradjat, dkk, Ilmu Pendidikan Islam, cet-VIII (Jakarta: Bumi Aksara, 2009), hal. 130.

${ }^{8}$ Hasan Basri, Kapita Selekta Pendidikan (Bandung: Pustaka Setia, 2012), hal. 20.
} 
dimiliki oleh bangsa tersebut.' Karena esensi dari pendidikan merupakan sebuah proses transfer nilai, pengetahuan dan ketrampilan dari generasi tua kepada generasi muda agar generasi muda mampu hidup..$^{10}$

Pendidikan juga menjadi tolak ukur bagi suatu bangsa, dan menjadi cermin kepribadian masyarakatnya. Dalam konteks ini Muhammad Noer Syam dalam bukunya filsafat pendidikan mengemukakan bahwa:

"Hubungan masyarakat dengan pendidikan menampakkan hubungan korelasi yang positif. Artinya, pendidikan yang maju dan modern akan menghasilkan masyarakat yang maju dan modern pula. Sebaliknya pendidikan yang maju dan modern hanya ditemukan dan di selenggarakan oleh masyarakat yang maju dan modern"."

Lebih tegas, Muhammad Kosim mengemukakan bahwa eksistensi pendidikan merupakan sarana yang dapat membantu individu dan masyarakat menuju kemajuan dan kecemerlangan. Selain itu, pendidikan juga bertujuan mendorong terciptanya tatanan kehidupan masyarakat ke arah yang lebih baik. ${ }^{2}$

Pentingnya pendidikan bagi suatu bangsa, menggugah pemerintah Indonesia mengeluarkan suatu kebijaksanaan yang dituangkan dalam Undang-undang RI Nomor 2 Tahun 1989 tentang sistem pendidikan nasional, yang telah disahkan dan diundangkan pada tanggal 27 maret 1989.

Armai Arief dalam bukunya menjelaskan bahwa salah satu isi dari Undang-undang RI Nomor 2 Tahun 1986 berkaitan dengan tujuan pendidikan nasional, yaitu mencerdaskan kehidupan bangsa dan mengembangkan manusia Indonesia seutuhnya, yaitu manusia yang beriman dan bertaqwa kepada Tuhan Yang Maha Esa dan berbudi pekerti luhur, memiliki pengetahuan dan keterampilan, kesehatan jasmani dan ruhani, kepribadian yang mantap dan mandiri, serta rasa tanggung jawab kemasyarakatan dan kebangsaan. ${ }^{13}$

${ }^{9}$ Haidar Putra Daulay, Pendidikan Islam dalam Sistem Pendidikan Nasional di Indonesia, cetakan III (Jakarta: Prenada Media Group, 2007), hal. 9.

10 Abdul Majid, Belajar dan Pembelajaran Pendidikan Agama Islam (Bandung: Remaja Rosdakarya, 2012), hal. 12.

11 Mohammad Noer Syam, Filsafat Pendidikan dan dasar Filsafat pendidikan pancasila, (Surabaya: Usaha Nasional, 1991), hal. 348.

${ }^{12}$ Muhammad Kosim, Pemikiran Pendidikan Islam Ibn Khaldun: Kritis, Humanis dan Religius (Jakarta: Rineka Cipta, 2012), hal. 59.

${ }^{13}$ Armai Arief, Reformulasi Pendidikan Islam, cetakan II (Ciputat: CRSD Press, 2005), hal. 17. 
Melihat penjelasan Armai Arief diatas menjadi semakin jelas akan fungsi dan pentingnya pendidikan baik bagi individu, masyarakat, bangsa dan negara yaitu mewujudkan kehidupan yang baik secara jasmani dan ruhani serta meningkatkan mutu dan kualitas kehidupan manusia sehingga mampu membawa pada kemajuan masyarakat, bangsa dan negara.

Dalam konteks Indonesia, jalur pendidikan telah mengalami berkembangan seiring dengan zaman. Pendidikan yang berbasis pada model pesantren, langgar, masjid merupakan model pendidikan awal di Indonesia..$^{14}$ Model pendidikan langgar, masjid dan lain sebagainya itu pada saat ini sering diistilahkan dengan pendidikan non formal. Selain model pendidikan non formal, model pendidikan juga berkembang dengan munculnya sekolahsekolah seperti SD, SMP atau SMA atau yang sering disebut dengan jalur pendidikan formal.

Majelis ta'lim merupakan salah satu pendidikan non formal Islam yang memiliki kurikulum tersendiri, diselenggarakan secara berkala dan teratur, dan diikuti oleh jamaah yang relatif banyak, bertujuan untuk membina dan mengembangkan hubungan yang santun dan serasi antara manusia dengan Allah SWT, antara manusia dengan sesamanya, serta antara manusia dengan lingkungannya, dalam rangka membina masyarakat yang bertaqwa kepada Allah SWT. . $^{5}$

Salah satu hal yang menjadi tujuan majelis ta'lim adalah menambah ilmu dan keyakinan agama, yang akan mendorong pengamalan ajaran agama yang diwujudkan dengan melakukan kegiatan-kegiatan keagamaan, kontak sosial yakni silaturrahmi, dan meningkatkan kesadaran dalam kesejahteraan rumah tangga dan lingkungannya. ${ }^{16}$

Kegiatan keagamaan di majelis ta'lim bersifat fleksibel. Karena itulah pendidikan majelis ta'lim menjadi alternatif bagi masyarakat yang tidak memiliki cukup waktu untuk belajar agama di lembaga pendidikan formal." Adapun kegiatan keagamaan itu sendiri adalah suatu aktifitas

${ }^{14}$ Ali Hasan dan Mukti Ali, Kapita Selekta Pendidikan Islam, cetakan II (Jakarta: Pedoman Ilmu Jaya, 2009), hal. 1.

${ }^{15}$ Hasbullah, Kapita Selekta Pendidikan Islam, (Jakarta: Raja Grafindo Persada, 1996), hal. 95. hal. 78.

${ }^{16}$ Tutty Alawiyah, Strategi Dakwah di Lingkungan Majelis Ta'lim, (Bandung: Mizan, 1997),

${ }^{17}$ Helmawati, Pendidikan Nasional dan Optimalisasi Majelis Ta'lim, (Jakarta: Rineka Cipta, 2013), hal. 78. 
keagamaan yang dilakukan oleh orang-orang muslim dengan tujuan meningkatkan ketaqwaannya kepada Allah SWT, serta mengharapkan akan ridlo-Nya. Kegiatan ini biasanya diatur dan dibina lansung oleh pemuka agama setempat yang bekerja sama dengan takmir masjid dan masyarakat sekitar.

Religiusitas adalah adalah perilaku Religius. Kata religius berasal dari kata religi yang akar katanya adalah Religure yang berarti mengikat. Dari sini dapat diartikan bahwa religi (agama) memiliki aturan-aturan yang mengikat dan harus dilaksankan oleh pemeluknya. Ajaran agama berfungsi untuk mengikat dan menyatukan sesorang atau sekelompok orang dalam berhubungan dengan Tuhannya, semua manusia dan alam sekitarnya. Kemudian menurut R. Stark dan C.Y. Glock, sebagaimana dikutip oleh Djamaluddin Ancok dan Fuat Nashori Suroso dalam bukunya, dikatakan bahwa keberagamaan atau religiusitas mengandung lima macam dimensi, yaitu dimensi keyakinan, dimensi peribadatan atau praktik agama, dimensi penghayatan, dimensi pengamalan dan dimensi pengetahuan agama. ${ }^{18}$ Lebih lanjut, Djamaluddin menerangkan bahwa rumusan tentang religiusitas tersebut, apabila dilihat dengan kacamata Islam akan nampak persamaannya, meskipun tidak sepenuhnya sama. Dimensi keyakinan dapat disejajarkan dengan akidah, dimensi praktik agama dapat disejajarkan dengan syariah dan dimensi pengamalan dapat disejajarkan dengan akhlak. ${ }^{19}$

Dengan melihat pada penjelasan diatas, maka dapat dikatakan bahwa keberagamaan atau religiusitas sendiri adalah sesuatu yang amat penting dalam kehidupan manusia. Hal ini karena, manusia dalam berbagai aspek kehidupanya akan dipertanggungjawabkan setelah meninggal dunia. Aktifitas beragama yang erat berkaitan dengan religiusitas, bukan hanya terjadi ketika melakukan ritual (ibadah) tetapi juga aktivitas lain yang didorong kekuatan batin. Jadi sikap religiusitas merupakan integrasi secara komplek antara pengetahuan agama, perasaan serta tindakan keagamaan dalam diri seseorang.

Tingkat religiutas adalah kadar atau tingkat keterikatan manusia terhadap agamanya. Seseorang yang memiliki keterikatan religiuitas yang

\footnotetext{
${ }^{18}$ Djamaluddin Ancok dan Fuat Nashori Suroso, Psikologi Islami: Solusi Islam atas ProblemProblem Psikologi, (Yogyakarta: Pustaka Pelajar, 2011), Cet. VIII, hal. 77.

${ }^{19}$ Ibid., hal. 80.
} 
lebih besar maka akan menjalankan aturan-aturan dan kewajiban-kewajiban agamanya dengan patuh. Orang seperti ini dapat dikatakan sebagai seseorang yang memiliki tingkat religiuitas yang lebih tinggi dari pada orang yang tidak menjalankan aturan-aturan dan kewajiban-kewajiban agamanya.

Dengan adanya majelis ta'lim yang didalamnya terdapat kegiatankegiatan keagamaan dan diiringi dengan wejangan-wejangan atau petuahpetuah maka terciptalah suasana keagamaan yang lebih baik dan maju dari sebelumya, dan terlihat sangat jelas dengan terwujudnya peningkatan keagamaan atau religiusitas di masyarakaya tersebut. serta dengan adanya usaha sadar yang dilakukan untuk menyakinkan, memahamkan, dan mengamalkan ajaran Islam pada masyarakat melalui pendidikan non formal atau pendekatan dengan kegiatan kegiatan keagamaan yang dilakukan sebagai aktifitas rutinan. ${ }^{20}$

Dengan demikian dapat dikatakan bahwa dengan pendidikan non formal di masyarakat yakni majelis ta'lim serta kegiatan-kegiatan keagamaan mingguan yang ada dan merambah dimasyarakat dapat meningkatkan religiusitas yakni pengetahuan dan pemahaman agama yang lebih di masyarakat, khususnya di perumahan Jiwan 002/006, Ngemplak, Kartasura, Sukoharjo. Oleh karena itu menarik diadakan penelitian tentang majelis ta'lim dan hubungannya dengan peningkatan religiusitas di perumahan Jiwan 002/006, Ngemplak, Kartasura, Sukoharjo. Tempat ini adalah salah satu lokasi yang asal mulanya dikatakan sebagai masyarakat non-muslim dan abangan yakni minim akan pengetahuan agama kemudian dengan diadakannya majelis ta'lim dan kegiatan keagamaan yang di bawa oleh pendatang baru yakni ustadz, lambat laun pendidikan agama Islam dan masalah-masalah keagamaan terlihat lebih berkembang.

Menurut makna bahasa, majelis ta'lim berasal dari dua kata, yaitu majelis dan ta'lim. Majelis merupakan isim makan dari kata kerja (fi'il) jalasa sehingga makna majelis adalah tempat untuk duduk. ${ }^{21}$ Sedangkan kata ta'lim merupakan bentuk masdar dari kata 'allama yang berarti pengajaran. Dengan definisi itu, dapat dipahami bahwa majelis ta'lim adalah tempat untuk melakukan pengajaran. Menurut Helmawati, majelis ta'lim adalah

${ }^{20}$ Abdul Madjid, Op. Cit., hal. 133.

${ }^{21}$ Ahmad Warson Munawir, Al-Munawir Kamus Arab-Indonesia, (Surabaya: Pustaka Progresif, 2002), hal. 1038. 
tempat pengajaran atau pengajian bagi orang-orang yang ingin mendalami ajaran-ajaran Islam.22

Berkaitan dengan kata ta'lim, dalam bahasa arab dikenal beberapa kata yang bersinonim atau memiliki arti yang sama dengan kata tersebut, yaitu kata tarbiyah dan ta'dib. Dody S. Truna dan Rudi Ahmad Suryadi mendefinisikan tarbiyah dengan makna educate yang berarti berkembang. Dengan definisi itu, maka tarbiyah lebih mengacu pada pengembangan potensi jasmani dan kecerdasan kognisi, belum menyentuh pada aspek manusia yang lainnya. ${ }^{23}$ Sejalan dengan penjelasan tersebut, Muhibbin Syah juga memberikan definisi tarbiyah, yaitu proses persiapan dan pengasuhan manusia pada fase-fase awal kehidupannya yakni pada tahap perkembangan masa bayi dan kanak-kanak. ${ }^{24}$

Menurut penjelasan Hasan Bashri, kata ta'dib mengandung pengertian sebagai proses pengenalan dan pengakuan secara berangsurangsur yang ditanamkan dalam diri manusia tentang tempat-tempat yang tepat dari segala sesuatu didalam tatanan penciptaan, kemudian membimbing dan mengarahkannya kepada pengakuan dan pengenalan kekuasaan dan keagungan Tuhan di dalam tatanan wujud dan keberadaan-Nya. ${ }^{25}$ Melihat pada definisi ta'lim, tarbiyah dan ta'dib dapat diambil pemahaman bahwa kata tarbiyah memiliki cakupan yang lebih luas dari ta'lim dan ta'dib. Erwati Aziz dalam bukunya juga mengemukakan perbedaan antara tiga kata tersebut. Menurutnya, ta'lim lebih menitikberatkan pada pengajaran yang lebih terfokus pada pengetahuan, kecerdasan dan keterampilan. Kata ta'dib, lebih terfokus pada pendidikan akhlak dan budi pekerti. Sedangkan kata tarbiyah memiliki makna yang lebih umum dari dua kata tersebut yang mencakup mendidik, mengajar mengasuh dan lain sebagainya..$^{26}$

Majelis Ta'lim merupakan merupakan model pendidikan yang banyak berkembang di masyarakat. Perkembangan kuantitas majelis ta'lim tersebut memberikan gambaran akan pentingnya ilmu dan pendidikan dalam

${ }^{22}$ Helmawati, Pendidikan Nasional dan Optimalisasi Majelis Ta'lim, (Jakarta: Rineka Cipta, 2013), hal. 78.

${ }^{23}$ Dody S. Truna dan Rudi Ahmad Suryadi, Paradigma Pendidikan Berkualitas, (Bandung: Pustaka Setia, 2013), hal. 20.

${ }^{24}$ Muhibbin Syah, Psikologi Pendidikan dengan Pendekatan Terbaru, (Bandung: Remaja Rosdakarya, 2014), Cet. XIX, hal. 32.

${ }^{25}$ Hasan Basri, Landasan Pendidikan (Bandung: Pustaka Setia, 2013), hal. 24.

${ }^{26}$ Erwati Aziz, Prinsip-Prinsip Pendidikan Islam (Solo: Tiga Serangkai, 2003), hal. 25. 
kehidupan manusia. Sebagai lembaga pendidikan non formal, majelis ta'lim memiliki kurikulum tersendiri, diselenggarakan secara berkala dan teratur dan diikuti oleh jamaah yang relatif banyak, bertujuan untuk membina dan mengembangkan hubungan yang santun dan serasi antara manusia dengan Allah SWT, antara manusia dengan sesamanya, serta antara manusia dengan lingkungannya, dalam rangka membina masyarakat yang bertaqwa kepada Allah SWT. ${ }^{27}$

Salah satu hal yang menjadi tujuan Majelis Ta'lim adalah menambah ilmu dan keyakinan agama, yang akan mendorong pengamalan ajaran agama yang diwujudkan dengan melakukan kegiatan-kegiatan keagamaan, kontak sosial yakni silaturrahmi, dan meningkatkan kesadaran dalam kesejahteraan rumah tangga dan lingkungannya.$^{28}$

Kegiatan keagamaan di Majelis Ta'lim bersifat fleksibel. Karena itulah pendidikan Majelis Ta'lim menjadi alternatif bagi masyarakat yang tidak memiliki cukup waktu untuk belajar agama di lembaga pendidikan formal..$^{29}$ Pada umumnya Majelis Ta'lim adalah lembaga swadaya masyarakat murni, yang dilahirkan, dikelola, dipelihara, dikembangkan dan didukung oleh anggotanya. Oleh karena itu, Majelis Ta'lim merupakan wadah masyarakat untuk memenuhi kebutuhan mereka sendiri, atau sebagai lembaga swadaya masyarakat yang hidupnya didasarkan kepada " $t a$ 'awun dan ruhama u bainahum".

Dari pengertian tersebut diatas, tampak bahwa majelis ta'lim diselenggarakan berbeda dengan lembaga pendidikan Islam lainnya, seperti pesantren dan madrasah, baik menyangkut system, materi maupun tujuannya. Pada majelis ta'lim terdapat hal-hal yang cukup membedakan dengan yang lain, diantaranya:

1. Majelis Ta'lim adalah lembaga pendidikan non formal Islam.

2. Waktu belajarnya berkala tapi teratur, tidak setiap hari sebagaimana halnya sekolah atau madrasah.

\footnotetext{
${ }^{27}$ Hasbullah, Kapita Selekta Pendidikan Islam, (Jakarta: Raja Grafindo Persada, 1996), hal. 95. hal. 78 .

${ }^{28}$ Tutty Alawiyah, Strategi Dakwah di Lingkungan Majelis Ta'lim, (Bandung: Mizan, 1997),

${ }^{29}$ Helmawati, Pendidikan Nasional dan Optimalisasi Majelis Ta'lim, (Jakarta: Rineka Cipta, 2013), hal. 78.
} 
3. Pengikut atau pesertanya disebut jamaah (orang banyak), bukan pelajar atau santri. Hal ini didasarkan kepada kehadiran di majelis ta'lim bukan merupakan kewajiban sebagaimana dengan kewajiban murid menghadiri sekolah atau madrasah.

4. Tujuannya yaitu memasyarakatkan ajaran Islam. ${ }^{30}$

Dengan adanya Majelis Ta'lim yang didalamnya terdapat kegiatankegiatan keagamaan dan diiringi dengan wejangan-wejangan atau petuahpetuah maka terciptalah suasana keagamaan yang lebih baik dan maju dari sebelumya, dan terlihat sangat jelas dengan terwujudnya peningkatan keagamaan atau religiusitas di masyarakaya tersebut. serta dengan adanya usaha sadar yang dilakukan untuk menyakinkan, memahamkan, dan mengamalkan ajaran Islam pada masyarakat melalui pendidikan non formal atau pendekatan dengan kegiatan kegiatan keagamaan yang dilakukan sebagai aktifitas rutinan. ${ }^{31}$

Materi (isi) dari Majelis Ta'lim merupakan pelajaran atau ilmu yang diajarkan dan disampaikan pda saat pengajian itu dilakukan, dan materimateri tersebut tidak jauh berbeda dengan pendidikan agama yang ada disekolah-sekolah atau madrasah-madrasah, dengan lain kata materi atau isi tetap mengacu pada ajaran agama Islam. Adapun pengklasifikasian materi pada Majelis Ta'lim yang diajarkannya antara lain adalah:32

1. Majelis Ta'lim yang tidak mengajarkan sesuatu secara rutin, tetapi hanya sebagai tempat berkumpul membaca shalawat bersama atau surat yasin, atau membaca maulid nabi dan sholat sunnah berjamaah dan sebulan sekali pengurus Majelis Ta'lim mengundang seorang guru untuk berceramah, dan ceramah inilah yang merupakan isi ta'lim.

2. Majelis Ta'lim yang mengajarkan pengetahuan dan keterampilan dasar ajaran agama, seperti belajar membaca al-Qur'an atau penerangan fiqih.

\footnotetext{
${ }^{30}$ Ani Susilowati, Pengaruh Pengajian Rutin Majelis Ta'lim Al-Mua'wwanah terhadap Akhlak Ibu-Ibu RT Muslim Benowo Surabaya, Skripsi, (Surabaya: Perpus IAIN Sunan Ampel, 2002), hal. 24.

${ }^{31}$ Abdul Madjid, Op. Cit., hal. 133.

32 Tutty Alawiyah As, Strategi Dakwah di Lingkungan Majelis Ta'lim (Bandung: Mizan, 1997), hal. 79.
} 
3. Majelis Ta'lim yang mengajarkan pengetahuan agama tentang fiqih, tauhid, atau akhlak yang diberikan dalam pidato-pidato muballigh kadang-kadang dilengkapi juga dengan tanya jawab.

4. Majelis Ta'lim seperti butir ke tiga dengan menggunakan kitab tertentu sebagai pegangan di tambah dengan pidato-pidato atau ceramah.

5. Majelis Ta'lim dengan pidato-pidato dan bahan pelajaran pokok yang diberikan teks tertulis. Materi pelajaran disesuaikan dengan situasi yang hangat berdasarkan ajaran Islam.

Majelis Ta'lim juga merupakan sebuah tradisi yang kental bagi masyarakat, dengan tradisi-tradisi semacam inilah pemahaman dan pengetahuan masyarakat luas tentang ajaran Islam dapat terjawab, walaupun tidak setiap hari mengikuti tetapi setidaknya mereka pernah mendengarkan ajaran Islam. ${ }^{33}$

Seperti halnya Majelis Ta'lim yang didalamnya ada kegiatan membaca shalawat bersama atau membaca surat yasin dapat menumbuhkan rasa cinta kepada nabi Muhammad serta mengetahui arti kehidupan yang sesungguhnya di dunia ini, kemudian dengan belajar membaca al-Qur'an akan mempermudah seseorang dalam memahami arti al-Qur'an.

Majelis Ta'lim yang mengajarkan pengetahuan agama tentang fiqih, tauhid, atau akhlak merupakan dimensi pembentukan awal dari pemahaman tentang ajaran Islam. Hal ini dikarenakan akidah (kepercayaan) adalah bidang teori yang dipercayai terlebih dahulu sebelum yang lain-lain, hendaknya kepercayaan itu bulat dan penuh tiada bercampur dengan syak, ragu dan kesamaan. ${ }^{34}$ Kemudian akidah merupakan seruan dan penyiaran yang pertama dari rasulullah dan dimintanya supaya di percaya oleh manusia dalam tingkat pertama (terlebih dahulu), dan dalam al-Qur'an akidah di sebut dengan kalimat "Iman".

Tentang akhlak yang merupakan ilmu budi pekerti yang membahas sifat-sifat manusia yang buruk dan baik, dengan ilmu akhlak akan memberikan jalan dan membuka pintu hati orang untuk berbudi pekerti yang

\footnotetext{
${ }^{33}$ Ani Susilowati, Pengaruh Pengajian Rutin Majelis Ta'lim Al-Mua'wwanah terhadap Akhlak Ibu-Ibu RT Muslim Benowo Surabaya, Skripsi, (Surabaya: Perpus IAIN Sunan Ampel, 2002), hal. 27.

${ }^{34}$ Syeikh Mahmud Shaltud, Aqidah dan Syari'ah Islam, (Jakarta: Bumi Aksara, 1994), hal. XIII.
} 
baik dan hidup berjasa dalam masyarakat, berbuat dan beramal untuk mencapai kebahagiaan dunia dan akhirat, menurut Imam Ghazali "Akhlak adalah sifat yang melekat dalam jiwa seseorang yang menjadikan ia dengan mudah bertindak tanpa banyak pertimbangan lagi" atau boleh juga dikatakan sudah menjadi kebiasaan. ${ }^{35}$

Dimensi akhlak, adalah materi yang paling sering disampaikan pada majelis ta'lim, hal ini bertujuan karena akhlak adalah sumber dari sikap atau berhubungan dalam kehidupan masyarakat sehari-hari dan secara sadar ataupun tidak akhlak itu akan tercermin dalam diri seseorang. Seperti halnya lapang dada, peramah, sabar (tabah), jujur, tidak dengki, dan sifat-sifat baik yang lainnya. Dengan sifat baik itu maka akan disenangi banyak orang dalam pergaulan dan hidup bermasyarakat dilingkungan. Begitu pula sebaliknya sifat iri hati, dengki, suka berdusta, pemarah, dan lainnya, maka akan dijauhi oleh masyarakat dilingkungannya.

Syariat atau fiqih diajarkan juga bertujuan untuk memberikan pemahaman kepada masyarakat tentang hubungannya baik dengan tuhan, sesama manusia, ataupun dirinya sendiri, sebagaimana maksud dari syariat sendiri adalah sebuah susunan, peraturan, dan ketentuan yang disyariatkan Tuhan dengan lengkap atau pokok-pokoknya saja supaya manusia mempergunakannya dalam mengatur hubungan dengan Tuhan. Hubungan dengan saudara seagama, hubungan saudara sesama manusia serta hubungannya dengan alam besar dan kehidupan..$^{36}$

\section{B. METODE PENELITIAN}

Penelitian ini termasuk jenis penelitian lapangan (field research), karena dalam memperoleh data harus datang langsung ke lapangan untuk melakukan pengamatan (observasi) dan memperoleh data melalui tanya jawab (wawancara). Adapun sifat penelitian ini adalah deskriptif analitik, dengan mendeskripsikan dan menafsirkan fenomena-fenomena yang ada, berkenaan dengan kondisi atau hubungan yang ada dalam obyek penelitian. Dalam penelitian ini, digunakan metode kuantitatif yaitu data-data yang terkumpul diklasifikasikan kedalam kategori-kategori berdasarkan

\footnotetext{
${ }^{35}$ Oemar Bakry, Akhlak Muslim, (Bandung: Angkasa, 1993), hal. 10.

${ }^{36}$ Syeikh Mahmud Shaltud, Aqidah dan Syari'ah Islam, (Jakarta: Bumi Aksara, 1994), hal. XIII.
} 
persamaan jenis data yang kemudian data tersebut diuraikan lalu dibandingkan antara satu sama lainnya sehingga diperoleh gambaran yang utuh tentang masalah yang diteliti.

\section{HASIL DAN PEMBAHASAN}

Majelis Ta'lim masyarakat di perumahan Jiwan Rt 002/ Rw. 003, desa Ngemplak, kecamatan Kartasura, Kabupaten Sukoharjo berdiri berawal dari adanya pembangunan Perumahan baru pada tahun 1999 di wilayah tersebut karena banyaknya warga yang datang dari luar daerah yang bekerja di Kartasura dan sekitarnya.

Pada tahap awal, terdapat 10 Kepala Keluarga (KK) yang menghuni perumahan ini. Para pendatang baru ini memiliki beragam profesi, ada yang berprofesi sebagai Dosen, Pegawai, Karyawan, Buruh, dan Guru. Setelah 3 bulan berjalan, maka terjadi interaksi sosial antar warga yang terkadang terjadi kesalah pahaman sehingga silaturahim menjadi kurang baik. Melihat pada keadaan tersebut, maka terdapat inisiatif untuk mengadakan acara silaturahim yang wajib dihadiri oleh seluruh warga yang dikemas dalam bentuk arisan. Kegiatan ini dilaksanakan dalam satu bulan sekali.

Setelah kegiatan pertemuan warga yang dilaksanakan dalam bentuk arisan tersebut berjalan selama 3 bulan, diusulkan kegiatan pengajian yang waktu dan tempat pelaksanaannya bersamaan dengan kegiatan arisan tersebut. Hal itu bertujuan untuk meningkatkan mutu pemahaman agama warga masyarakat yang memang secara umum masih sangat kurang.

Untuk memulai pengajian ini memang merupakan hal yang cukup sulit. Kesulitan ini disebabkan salah satunya karena sebagian besar penduduk masyarakatnya adalah non muslim. Sehingga, kegiatan pengajian hanya diisi dengan ceramah-ceramah oleh Bp. Jauhari, Bp. Hadi, Bp. Sidik, Bp. Abdul Ghofur, dan Bp. Mudhofir Abdullah secara bergantian kemudian ada sesi Tanya jawab.

Setelah kegiatan pengajian dalam bentuk ceramah ini berjalan, maka pada tahun 2013 diadakan kegiatan tahsin al-Qur'an untuk membenahi bacaan-bacaan al-Qur'an agar sesuai dengan kaidah ilmu tajwid. Kegiatan ini diikuti oleh peserta kurang lebih 20 orang dan diampu oleh dosen IAIN 
Surakarta yaitu bapak Sidik, S.Ag, M.Ag. Pada saat kegiatan tahsin ini juga diselingi dengan ceramah dan tanya jawab berkaitan dengan masalahmasalah agama.

Selanjutnya, pada tahun 2014 diadakan pembacaan rattib, mulai dari Rattib al-Haddad, Rattib al-Attas, dan Rattib al-Kubro. Pembacaan rattib ini dipimpin oleh bapak Abdullah Irfandi yang dibaca pada setiap ba'da maghrib dengan pembagian pembacaan rattib setiap malam selasa dan malam jum'at adalah Rattib al-Kubro. Selain hari itu membaca Rattib alAttas ataupun Rattib al-Haddad. Kegiatan ini diikuti peserta kurang lebih 24 orang.

Melihat pada data sejarah tersebut, maka dapat dilihat perkembangan majelis ta'lim yang terus berkembang khususnya dari sisi kuantitas, yaitu bertambahnya jumlah peserta. Perkembangan ini tentunya tidak dapat dilepaskan dari unsur-unsur penyebab, yang salah satunya adalah kesabaran dan keistiqamahan dari para pengasuh dalam mengelola Majelis Ta'lim tersebut. Seiring dengan perkembangannya, Majelis Ta'lim ini telah memiliki aktifitas rutin, diantaranya: 1) Pengajian umum yang dilaksanakan satu bulan sekali; 2) tahsin al-Qur'an yang dilaksanakan setiap satu minggu sekali dan 3) pembacaan rattib yang dilaksanakan setiap hari ba'da maghrib.

Majelis Ta'lim Masyarakat Di Perumahan Jiwan 002/006, Ngemplak, Kartasura, Sukoharjo dikelola oleh pengurus Majelis Ta'lim yang hanya dibuat secara sederhana, yaitu terdiri dari Ketua, sekretaris dan bendahara. Majelis Ta'lim Masyarakat Di Perumahan Jiwan 002/006, Ngemplak, Kartasura, Sukoharjo, diketua oleh Bapak Amin Taufiq dan sebagai Sekretaris adalah Bapak Arif Rahman Hakim. Sedangkan sebagai bendahara Majelis Ta'lim adalah Ibu Yuli. Begitulah gambaran tentang Majelis Ta'lim Masyarakat di Perumahan Jiwan 002/006, Ngemplak, Kartasura, Sukoharjo.

Tabel C.1. Rekapitulasi Prosentase Nilai Skor Tiap Item Pertanyaan Tentang Majelis Ta'lim

\begin{tabular}{lllll} 
No & Aspek yang diteliti & \multicolumn{1}{c}{$\begin{array}{c}\text { No. Item } \\
\text { Pertanyaan }\end{array}$} & Rata-Rata & Kategori \\
\hline \multirow{3}{*}{1} & $\begin{array}{l}\text { Kognitif } \\
\text { (Pengetahuan }\end{array}$ & 1 & 3.3 & Baik \\
\cline { 3 - 5 } & Agama) & 2 & 2.9 & Cukup Baik \\
\cline { 3 - 5 } & 3 & 3.2 & Baik
\end{tabular}




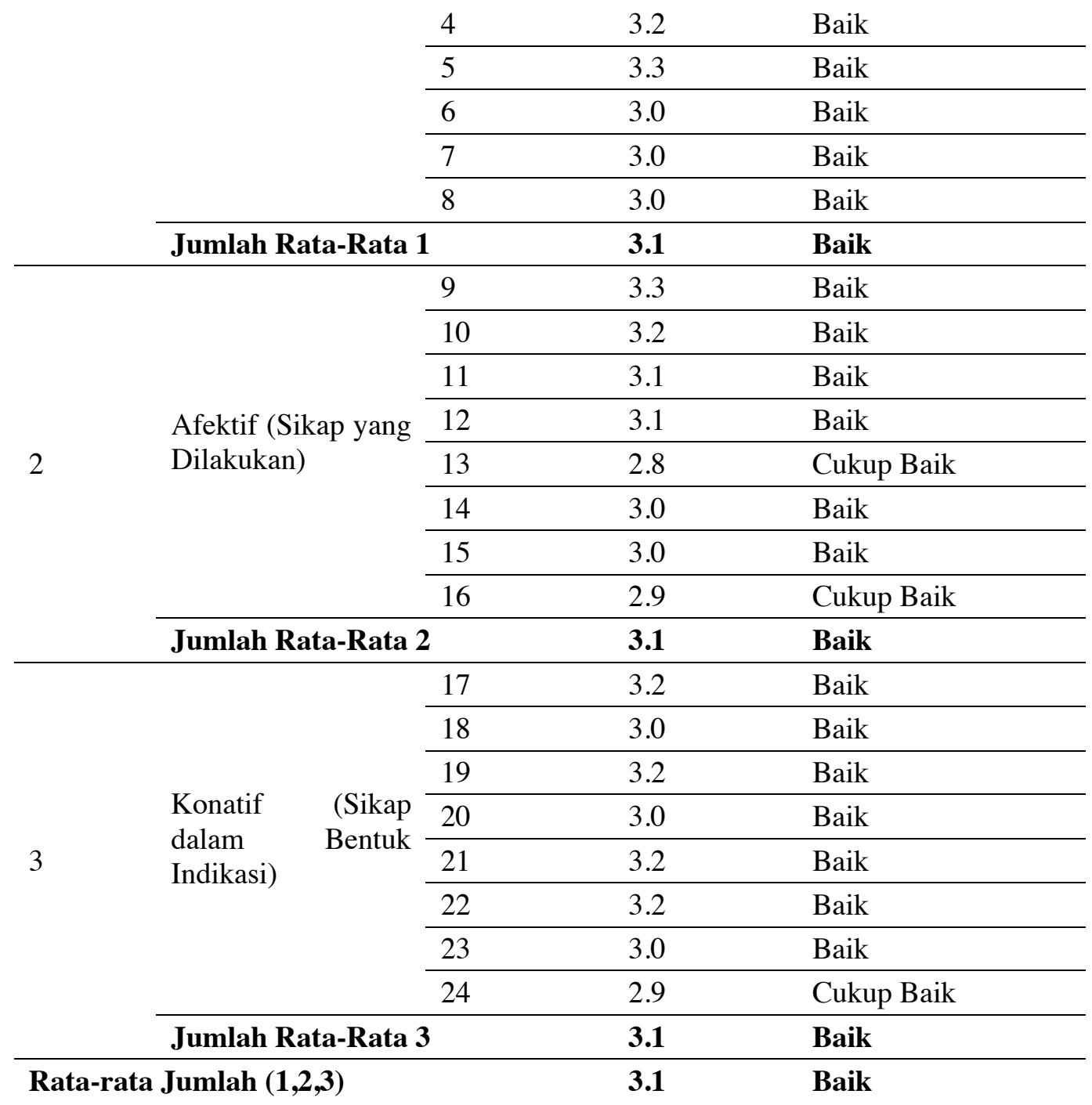

Berdasar tabel di atas dapat dijelaskan:

1. $76 \%-100 \%(3.0-4.0)=$ tergolong baik

2. $56 \%-75 \%(2.0-2.9)=$ tergolong cukup baik

3. $40 \%-55 \%(0-1.9)=$ tergolong kurang baik

Jadi penafsiran (kesimpulan) dari tabel tentang Majelis Ta'lim dengan melihat pada standar penafsiran di atas adalah sebagai berikut: 
1. Aspek kognitif diperoleh skor rata-rata sebesar 3.0 yang tergolong baik, hal ini dapat dilihat dengan masyarakat yang bisa memahami akan tata cara berwudlu (3.1), mengetahui perkara-perkara yang membatalkan wudlu (3.0), memahami tata cara ibadah sholat (3.0), mengetahui perkara yang membatalkan sholat (2.9), melafalkan do'a dan bacaan dalam sholat (3.2), mengetahui makna dari berpuasa (2.9), mengetahui dan melafalkan niat berpuasa (3.0), dan mengetahui perkara yang membatalkan puasa (2.8).

2. Aspek Afektif diperoleh skor rata-rata sebesar 3.0 yang tergolong baik, hal ini bisa dilihat dengan masyarakat yang dapat membedakan akhlak mahmudah dan madzmumah (3.1), melakukan hal yang baik seperti tolong menolong, sabar akan disenangi banyak teman (2.9), berlaku sombong, kikir, tidak akan mendapatkan keuntungan baik dari diri sendiri ataupun orang lain (3.4), mencuri, berjudi, minum- minuman keras adalah perbuatan yang tidak di sukai oleh allah (3.0), sebagai orang muslim, berzina adalah perbuatan yang dilaknat oleh Allah (2.9), tidak mengucilkan tetangga yang pernah berbuat kesalahan (3.2), minum-minuman keras adalah perkara yang sangat dilarang oleh agama (3.0) dan mengetahui perkara yang halal dan haram (2.8)

3. Aspek konatif diperoleh skor rata-rata sebesar 3.0 yang tergolong baik, hal ini terbukti dengan sikap yang dapat mempererat tali silaturahim antar teman, tetangga dan lainnya (2.7), menambah pengetahuan tentang agama Islam (2.9), sikap interaksi, saling tolong-menolong, bantu-membantu merupakan hal yang sangat dibutuhkan dalam hidup (2.9), mengetahui bahwa Bom bunuh diri bukan merupakan jihad di jalan Allah (3.5), Kegiatan Majelis Ta'lim dilakukan secara bergilir dari rumah ke rumah (2.9), Majelis Ta'lim diadakan satu kali dalam seminggu (2.9), Kegiatan Majelis Ta'lim bisa menenangkan hati yang resah (3.2), Majelis Ta'lim dapat membantu dalam memecahkan masalah-masalah agama (2.9).

Dari beberapa uraian di atas yang merujuk pada angket yang telah di sebarkan, maka dapat disimpulkan bahwa kegiatan Majelis Ta'lim yang ada di perumahan Jiwan Rt. 02/ Rw. 06, Ngemplak, Kartasura tergolong baik yakni dengan jumlah skor rata-rata 3.0 (Baik). 
ACADEMIA: Jurnal Ilmu Sosial dan Humaniora, Vol. 1 No 2 Februari 2019

Tabel C.2 Rekapitulasi Prosentase Nilai Skor Tiap Item Pertanyaan Tentang Peningkatan Religiusitas masyarakat

\begin{tabular}{|c|c|c|c|c|}
\hline No & Aspek yang diteliti & $\begin{array}{l}\text { No. Item } \\
\text { Pertanyaan }\end{array}$ & Rata-Rata & Kategori \\
\hline \multirow{6}{*}{1} & \multirow{5}{*}{ Keyakinan } & 1 & 3.0 & Baik \\
\hline & & 2 & 3.1 & Baik \\
\hline & & 3 & 2.9 & Baik \\
\hline & & 4 & 3.1 & Baik \\
\hline & & 5 & 3.3 & Baik \\
\hline & Jumlah Rata-Rata 1 & & 3.1 & Baik \\
\hline \multirow{6}{*}{2} & \multirow{5}{*}{ Ritual } & 6 & 3.2 & Baik \\
\hline & & 7 & 3.2 & Baik \\
\hline & & 8 & 3.3 & Baik \\
\hline & & 9 & 3.1 & Baik \\
\hline & & 10 & 3.1 & Baik \\
\hline & Jumlah Rata-Rata 2 & & 3.2 & Baik \\
\hline \multirow{6}{*}{3} & \multirow{5}{*}{ Pengetahuan Agama } & 11 & 3.4 & Baik \\
\hline & & 12 & 3.0 & Baik \\
\hline & & 13 & 3.1 & Baik \\
\hline & & 14 & 3.2 & Baik \\
\hline & & 15 & 3.0 & Baik \\
\hline & Jumlah Rata-Rata 3 & & 3.1 & Baik \\
\hline \multirow{6}{*}{4} & \multirow{5}{*}{ Pengalaman } & 16 & 2.9 & Cukup Baik \\
\hline & & 17 & 2.8 & Cukup Baik \\
\hline & & 18 & 2.9 & Cukup Baik \\
\hline & & 19 & 3.1 & Baik \\
\hline & & 20 & 3.4 & Baik \\
\hline & Jumlah Rata-Rata 4 & & 3.0 & Baik \\
\hline \multirow{6}{*}{5} & \multirow{4}{*}{ Pengamalan } & 21 & 2.9 & Cukup Baik \\
\hline & & 22 & 3.1 & Baik \\
\hline & & 23 & 3.2 & Baik \\
\hline & & 24 & 2.7 & Cukup Baik \\
\hline & Jumlah Rata-Rata 5 & & 3.0 & Baik \\
\hline & $\begin{array}{l}\text { Jumlah Total } \\
\text { Rata-Rata }\end{array}$ & & 3.1 & Baik \\
\hline
\end{tabular}

Hasil rekapitulasi tentang peningkatan religiusitas menunjukkan:

1. Aspek Keyakinan, di peroleh skor rata-rata sebesar 3.1 yang tergolong baik, hal ini terlihat pada skor yang di hasilkan tiap butir pertanyaan yakni $(3 \cdot 1,3.0,3.0,3.1,3.2)$, yang mana 
meliputi tentang keyakinan masyarakat terhadap agama Islam seperti adanya Rukun Iman, mati, rizki, mu'jizat dan lainnya.

2. Aspek Ritual, di peroleh skor rata-rata sebesar 3.1 yang tergolong baik, hal ini di buktikan dengan penyebaran skor nilai yakni $(3.1,3.0,3.2,3.1,3.2)$ yang mana dalam item pertanyaan meliputi tentang kegiatan ritual/ ibadah seseorang seperti sholat, puasa, shodaqoh, dan lainnya.

3. Aspek Pengetahuan Agama, diperoleh skor rata-rata sebesar 3.1 yang tergolong baik, hal ini terlihat pada skor yang di hasilkan tiap aitem pertanyaan yakni $(3.4,3.0,3.2,3.2,3.0)$ yang meliputi tentang seberapa banyak pengetahuan agama yang telah diketahui oleh masyarakat khususnya jama'ah Majelis Ta'lim.

4. Aspek Pengalaman, di peroleh skor rata-rata sebesar 3.0 dengan katagori baik. hal ini di buktikan dengan penyebaran skor nilai yakni $(2.8,2.9,2.9,2.9,3.5)$ yang mana aitem pertanyaannya meliputi tentang pengalaman seseorang terhadap agama Islam, seperti do'a yang merasa telah dikabulkan oleh Allah dan lainnya.

5. Aspek Pengamalan, diperoleh skor rata-rata sebesar 3.0 dengan katagori baik, hal ini terlihat pada skor yang di hasilkan tiap butir pertanyaan yakni $(2.9,2.9,3.2,2.9)$ yang meliputi tentang pengamalan seseorang terhadap agama Islam dalam kehidupan sehari-hari.

Dengan merujuk beberapa uraian di atas yakni dari hasil penyebaran angket, maka dapat di simpulkan bahwa peningkatan religiusitas masyarakat desa Tanjung dikatagorikan baik dengan jumlah skor rata-rata sebesar 3.1 (baik).

Setelah dilakukan usaha-usaha untuk meningkatkan religiusitas lewat majelis ta'lim, maka perlu dilakukan analisa pengaruh majelis ta'lim terhadap peningkatan religiusitas tersebut. Untuk mengetahui pengaruh variable X (Majelis Ta'lim) terhadap variable Y (Peningkatan Religiusitas) masyarakat di Perumahan Jiwan 002/006, Ngemplak, Kartasura, Sukoharjo atau menguji hipotesis yang diajukan peneliti maka menggunakan pendekatan statistik dengan teknik analisis persamaan regresi linier. 
Pengujian hipotesis, dilakukan berdasarkan pada data yang ada, baik berasal dari angket, wawancara, maupun observasi langsung kegiatan majelis ta'lim. Upaya ini dilakukan agar dapat diketahui secara valid adanya pengaruh majelis ta'lim terhadap peningkatan religiusitas masyarakat di Perumahan Jiwan 002/006, Ngemplak, Kartasura, Sukoharjo.

\section{KESIMPULAN}

Kegiatan Majelis Ta'lim di perumahan Jiwan Rt. 02/ Rw. 06, Ngemplak, Kartasura ada 3 (tiga) macam yaitu kegiatan pengajian rutin (ceramah umum) sebulan sekali, kegiatan tahsin al-Qur'an seminggu sekali, dan kegiatan dzikir berjama'ah (Rotib al Haddad, al Athas, dan al Kubro) setiap ba'da maghrib. Usaha-usaha peningkatan religiusitas masyarakat, yaitu dengan melakukan perencanaan dalam pengelolaan majelis taklim dan kemudian setelah rencana dilaksanakan perlu dilakukan evaluasi tentang ada dan tidaknya pengaruh pendidikan di majelis ta'lim dengan peningkatan religiusitas masyarakat.

Pengaruh Majelis Ta'lim di perumahan Jiwan Rt. 02/ Rw. 06, Ngemplak, Kartasura memiliki pengaruh yang sangat besar terhadap religiusitas masyarakat. Hal ini dibuktikan dengan analisa data lapangan yang menunjukkan adanya peningkatan keberagamaan (religiusitas) mulai dari keyakinan, pengetahuan, dan sikap beragama pada masyarakat di perumahan Jiwan Rt. 02/ Rw. 06, Ngemplak, Kartasura. Apabila majlis ta'lim di tingkatkan 40\%, maka religiusitas masyarakat akan bertambah $0,2427(40)=9,71$ angka. Dan dapat disimpulkan bahwa Ho ditolak dan Ha diterima, yakni ada pengaruh antara majlis ta'lim dan peningkatan religiusitas masyarakat di perumahan Jiwan Rt. 02/ Rw. 06, Ngemplak, Kartasura. 


\section{REFERENSI}

Alawiyah, Tutty, Strategi Dakwah di Lingkungan Majelis Ta'lim, Bandung: Mizan, 1997.

Ancok, Djamaluddin dan Suroso, Nashori, Fuat, Psikologi Islami: Solusi Islam atas Problem-Problem Psikologi, Yogyakarta: Pustaka Pelajar, 2011, Cet. 8.

Arief, Armai, Reformulasi Pendidikan Islam, Ciputat: CRSD Press, 2005, Cet. 2.

Aziz, Erwati, Prinsip-Prinsip Pendidikan Islam, Solo: Tiga Serangkai, 2003.

Bakry, Oemar, Akhlak Muslim, Bandung: Angkasa, 1993.

Basri, Hasan, Landasan Pendidikan, Bandung: Pustaka Setia, 2013.

Basri, Hasan, Kapita Selekta Pendidikan, Bandung: Pustaka Setia, 2012.

Daradjat, Zakiah, dkk, Ilmu Pendidikan Islam, Jakarta: Bumi Aksara, 2009, Cet 8 .

Daulay, Putra, Haidar, Pendidikan Islam dalam Sistem Pendidikan Nasional di Indonesia, Jakarta: Prenada Media Group, 2007, Cet. 3.

Djumali, dkk, Landasan Pendidikan, Yogyakarta: Gava Media, 2013.

Hasan, Ali dan Ali, Mukti, Kapita Selekta Pendidikan Islam, Jakarta: Pedoman Ilmu Jaya, 2009, Cet. 2.

Hasbullah, Kapita Selekta Pendidikan Islam, Jakarta: Raja Grafindo Persada, 1996.

Helmawati, Pendidikan Nasional dan Optimalisasi Majelis Ta’lim, Jakarta: Rineka Cipta, 2013.

Hidayah, Nur, Siti, Pengaruh Majelis Ta'lim Terhadap Peningkatan Religiusitas Masyarakat Desa Tanjung Kecamatan Kedamean Kabupaten Gresik, Skripsi, Surabaya: IAIN Sunan Ampel, 2009.

Jalaluddin dan Ramayulis, Psikologi Agama, Jakarta: PT. Raja Grafindo Persada, 1987.

Kosim, Muhammad, Pemikiran Pendidikan Islam Ibn Khaldun: Kritis, Humanis dan Religius, Jakarta: Rineka Cipta, 2012. 
Latif, Abdul, Pendidikan Berbasis Nilai Kemasyarakatan, Bandung: Refika Aditama, 2009, Cet. 2.

Madjid, Abdul, Pendidikan Agama Islam Berbasis Kompetensi, Bandung: PT Remaja Rosda Karya, 2005.

Mahmud, Sosiologi Pendidikan, Bandung: Pustaka Setia, 2012.

Majid, Abdul, Belajar dan Pembelajaran Pendidikan Agama Islam, Bandung: Remaja Rosdakarya, 2012.

Munawir, Warson, Ahmad, Al-Munawir Kamus Arab-Indonesia, Surabaya: Pustaka Progresif, 2002.

Poerwadarminto, W.J.S, Kamus Umum Bahasa Indonesia, Jakarta: Balai Pustaka, 1993

Shaltud, Mahmud, Syeikh, Akidah dan Syari'ah Islam, Jakarta: Bumi Aksara, 1994.

Shihab, Quraish, Muhammad, Wawasan Al-Qur'an: Tafsir Tematik atas Pelbagai Persoalan Umat, Bandung: Mizan, 2007.

Shohib, Muhammad, Al Quran dan Terjemahannya, Jakarta: Kementerian Agama RI, 2011.

Suharto, Toto, Pendidikan Berbasis Masyarakat: Relasi Negara dan Masyarakat dalam Pendidikan, Yogyakarta: LKiS, 2012.

Susilowati, Ani, Pengaruh Pengajian Rutin Majelis Ta'lim Al-Mua'wwanah Terhadap Akhlak Ibu-Ibu RT Muslim Benowo Surabaya, Skripsi, Surabaya: Perpus IAIN Sunan Ampel, 2002.

Syah, Muhibbin, Psikologi Pendidikan dengan Pendekatan Terbaru, Bandung: Remaja Rosdakarya, 2014, Cet, 19.

Syam, Noer, Mohammad, Filsafat Pendidikan dan dasar Filsafat pendidikan pancasila, Surabaya: Usaha Nasional, 1991.

Truna, Dody S dan Suryadi, Ahmad, Rudi, Paradigma Pendidikan Berkualitas, Bandung: Pustaka Setia, 2013.

Usman, Sunyoto, Sosiologi: Sejarah, Teori dan Metodologi, Yogyakarta: Pustaka Pelajar, 2012. 
ACADEMIA: Jurnal Ilmu Sosial dan Humaniora, Vol. 1 No 2 Februari 2019

Yusanto, Ismail, Muhammad, Menggagas Pendidikan Islami, Bogor: Al Azhar Press, 2004. 